Biology | Nobuharu Inaba

\title{
A new biological approach to control harmful algal blooms
}

Harmful algal blooms can be extremely destructive for loca marine life. The acceleration of geographic expansion and ans of climate change have recently been reported September 2019, the first report published from the United Nations' Intergovernmental Panel (IPCC) linked climate change to harmful algal blooms. Existing methods to control them are often inadequate and Dr Nobuharu Inaba, Civil Engineering Research Institute for Cold Region in Japan, is working on a novel biological approach. Using bacteria with the ability to eliminate these harmful algae, his new method shows promising results.

\section{Igal blooms pose severe} areas of the world. Blooms are characterised by an excessive a algae, which can affect marine wildife, as well as contaminate food resources, such as cultured fish and bivalves. These blooms occur when excessive amounts of nutrients are released into the water, creating the perfect conditions for plankton to proliferate and form dense blooms. In extreme situations, it may even have fatal consequences for humans, marine mammals and other aquatic life due to exposure to toxic products.

To avoid these issues, an effective and eco-friendly strategy to treat these algal blooms is imperative. In Japan, for example, valious moth have been atempled, including policy changes to ways to reduce the amount of nutrents from fish farms released into the water
However, there is growing concern that these options may not be enough crmay sometim es lead to negative

Keen to develop a way to limit these algal blooms, Dr Nobuharu Inaba and his team based at the Civil Engineering Institute for Cold Region in Japan, wanted to explore a new biologica approach. In essence, a natural way involve harsh chemicals or complex separation processes.

\section{ANEW BIOLOGICAL APPROACH} Surprisingly, when considering this a possible solution came in the form of tiny bacteria. Over the past few years, bacteria that are densely populated bocteriated in seagrass beds which can suppress controlling excessive algl growh Dr Inaba likens the function of the problem can have major repercussion

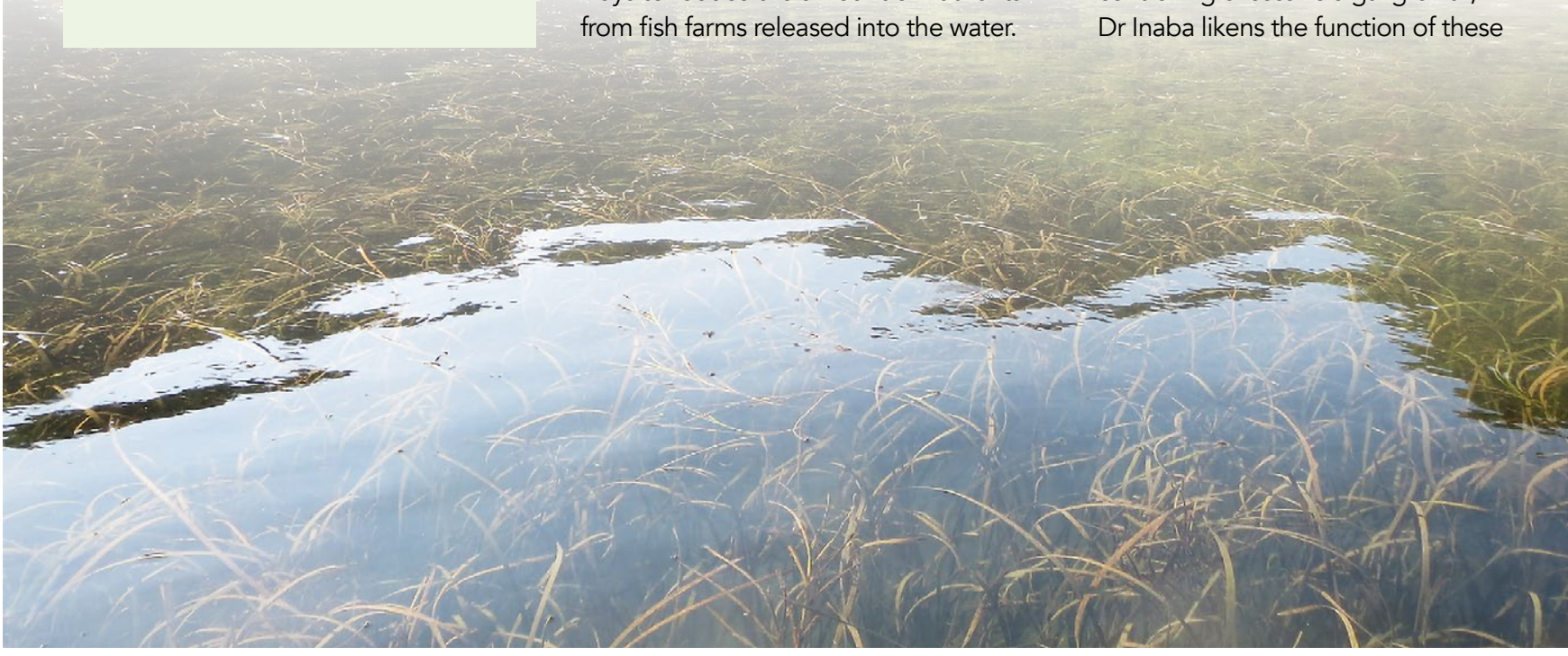

acteria to the ocean's immune ystem. He explains: "We have been alga looms using ngturativing microorganisms associated with seagrass beds. We propose novel strategies to mitigate the occurrence of algal blooms by restoration, protection " or the introduction of seagrass beds."

This approach is certainly not a new idea. Biological control has been used in agriculture for decades to protect crops or for clean-up operations in severely polluted areas. However, water is not the same as land, and differences between these two environments must be assessed before starting to use bacteria in open

\section{WORLDWIDE PHENOMENON}

\section{Werrass beds seem to be the centre}

of activity for these helpful bacteria.

These underwater plants occupy vast

extensions in sheltered and relatively

shallow coastal zones and prefer muddy

or sandy bottoms. They can protect

and feed hundreds of different aquatic

species, from fish and molluscs to worms

and nematodes.

However, in-depth studies to characterise the link between bacteria and seagrass beds are still scarce. As a first step, Dr Inaba wanted to assess distribution and changes throughout the year of these algicidal and growth-inhibiting bacteria. He targetted a specific alga common in flooms. Chat spella antiqua, the noto i fish-killing raphidop

The genus of Chattonella, a unicellular lgae, has been spotted in southeast Asia, USA, Brazil, Australia and even in the North Sea in Europe. The exact mechanism that leads to fish death is not yeet fully understood, but it's likely to substances. Also, in a rather crude way these algal blooms can suffocate the fis by blocking the gills.

Dr Inaba opted to test two location southern Ariake Sea in Japan and Puget Sound in Washington, USA. In both places, the researchers found high amounts of harmful algal growthresearch has den seagrass beds. "Our research has demonstrated that bacteria

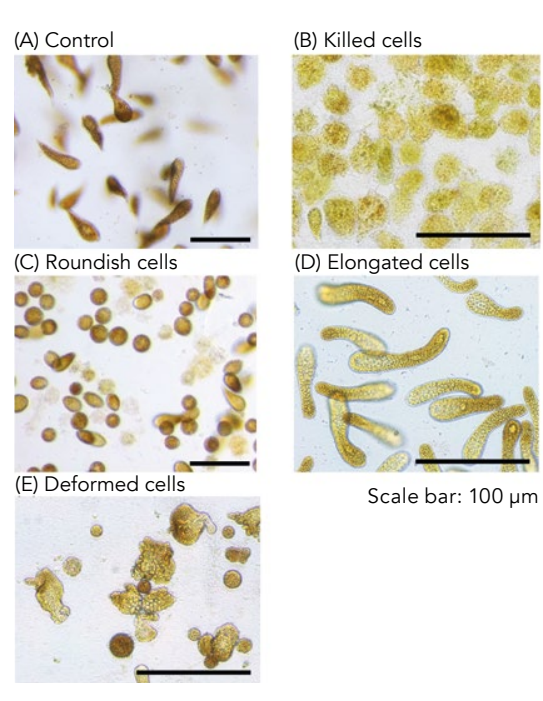

The cells of Chattonella antiqua were negatively
affected by different types of in a seagrass bed. (A) control, (B) killed cells, (C) growth inhibition by no motility-inducing
bacteria, (D) growth inhibition by elongationinducing bacteria, (E) growth hinhibition by
deformation-indcing bacteria

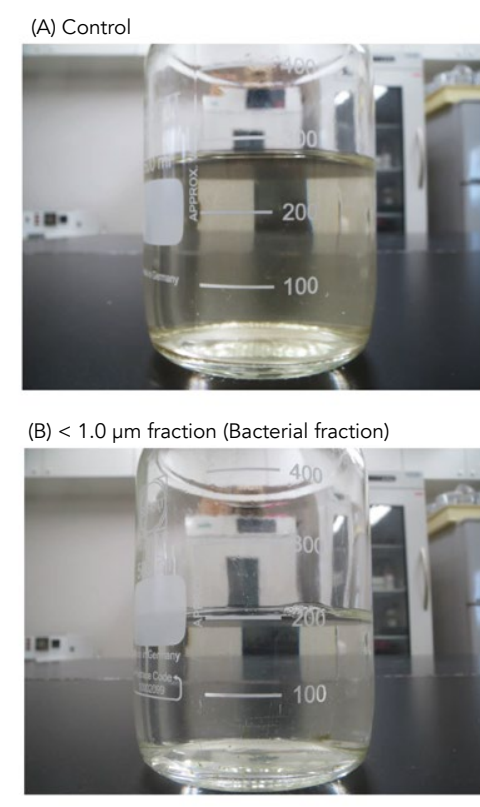
Pictures of representative state of control fraction
using $0.1-\mu$ m filtered seavater ( $A$; and Chattonella
incubated with $1.0 \mu \mathrm{mm}$ fittered seawater (Bacterial fraction: B), both collected from seagrass bed. Artificial Chattonella blooms were completely
terminated in the "Bacterial fraction" after 8 days.

Our research has demonstrated that bacteria which inhibit the growth of species of harmful algae are commonly distributed at seagrass beds and are likely to be a worldwide phenomenon.

harmful algae are commonly distributed at seagrass beds and are likely to be a worldwide phenomenon

What's more, the abundance of these algal growth-limiting bacteria followed followed by a sharp decrese in Siptom when seagrass withered The researchers speculated that the presence of seagrass stimulates the proliferation of these bacteria. While growing, seagrasses provide large amounts of suitable organic matter which can be an accessible food resource for the bacteria.

Woryingly, this also means that in the absence of seagrass, these bacteria find it difficult to grow and prosper, thus removing any control of harmful algae. For example, the researchers found high levels of toxic algal cysts in Westcott Bay, where seagrass disappeared back in 2002. The germination of those cysts could function algal blooms in the area.
IS IT POSSIBLE TO CONTROL ALGA BLOOMS WITH BACTERIA? The fact that seagrass can provide suggests a potential mere bacteria limit the proliferation of harmful algae. (n) developing ways to restore and protect

With this in mind, Dr Inaba's goal was to examine how these bacteria present in seagrass beds react to an artificial algal bloom. "To our knowledge, this is bacteria, routinely detected in seawater have been used to mitigate an artificiallyinduced Chattonella bloom."

Results soon confirmed that bacterial of Chatonella peaked on the second day of the experimenter end the the first study in which growth-limiting communities in seagrass could limit artificial Chattonella blooms. The levels 

the growth of tested two harmful algal species

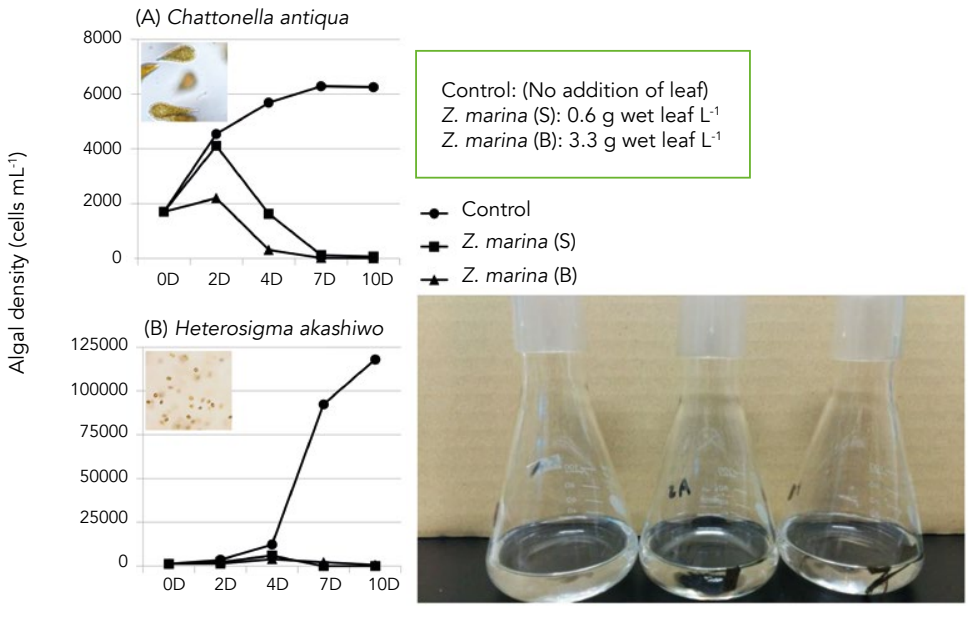

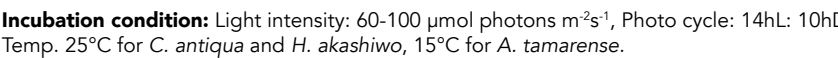

to a gradual increase in growth-limiting experiment. Even with the presence of natural predators, such as nanoflagellates, these helpful bacteria continued to force the number of Chatonella cells to drop. For Dr Inaba, this is conclusive evidence that these bacteria can "suppress the artificial blooms of the fish-killing raphidophyte flagellate Chatonella antiqua, even in the presence of bacterial competitors and predators.

The researchers also spotted a reduction in water turbidity when these bacteria were present. This decrease was not surprising, as seagrass beds are vital for puritying water and clear water means less facilita algae. Ulimately, lower turbidity

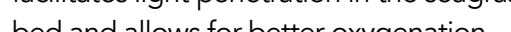
For Dr Inaba, these bacteria not only control algal blooms but also "help to maintain the health and ecosystem diversity within coastal seagrass beds".

Despite the progress in this field, the mechanism of action for these algal-killing bacteria is not yet entirely understood. However, Dr Inaba explains some genetic clues: analysis shows that considerable numbers of bacteria that suppress algal growth have the necessary cellus It's possise thats fubstan of cellulose. It's possible that substances released by these bacteria, such as glycoside hydrolases (which can degrade Complex polysaccharides)

RESTORE AND PROTECT

It's still early days, but these findings may be the starting point for an ecoblooms. This work also emphasises the importance of restoring and protecting seagrass beds in coastal ecosystems, in particular in regions frequently affected by algal blooms or in locations used in ood production for humans.

These findlings may be the starting point for an eco-friendly and effective way to control algal blooms by preserving the microbial assemblages as an integral part of restored seagrass meadows.

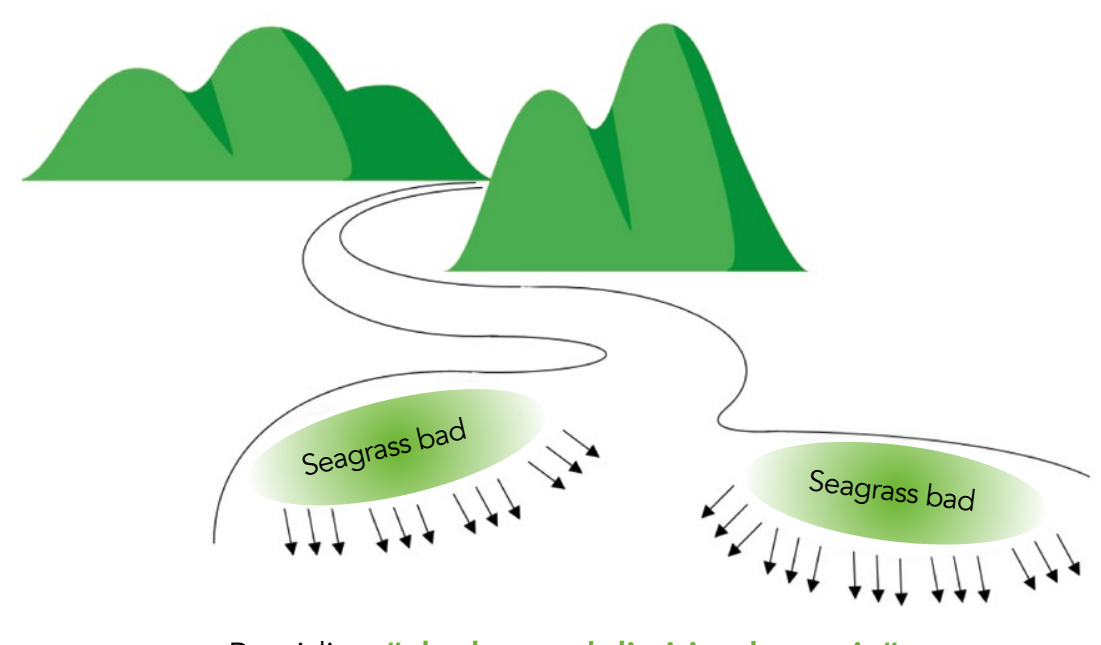

Providing "algal growth-limiting bacteria"

to surrounding water, mitigating Harmful Algal Blooms (HABs)

\section{Dr Nobuharu Inaba}

inaba-n@ceri.go.jp T: +81-11-841-1695 W: http://www.ceri.go.jp/index.html

Research Objectives

Nobuharu Inaba's research in aquatic science includes microbial interaction and its application

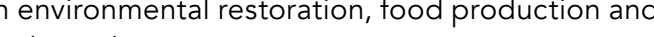
biological engineering.

\section{Detail}

Nobuharu Inaba

isheries Engineering Research Team

Cold Region

(niravitute

Sapporo, 062-8602, JAPAN

Nobuharu Inaba received his Ph.D. in Fisheries Science from Hokkaido University in 2016. He has been a tenure track researcher at Fisheries Engineering Research Team, Civil Engineering Research Institute for Cold Region in Japan since 2018.

Funding

( Fisheries Research Council of Japan

- The University of Wash

Exchange Program

(Ps//depts washington.edu/fh// morse/index.html

\section{Collaborators}

Emeritus Prof Ichiro Imai (Hokkaido University, Japan)

- Dr Vera L. Trainer (NOAA Fisheries, USA)

Dr Sandy Wyllie-Echeverria (University of

- Dr Tomoko Sakami (Japan Fisheries Research and Education Agency)

\section{CERI}

\section{References}

Inaba N, Trainer V, Nagai S, Kojima S, Sakami T, Takag $T$, and Imai ( (2O $V$ ) Dynamics of seagrass bed microbial communities in artificial Chattonella blooms: A laboratory microcosm study. Harmful Algae, 84, 139-150.

Inaba N, Nagai S, Sakami T, Watanabe T, Araki K, Kawasaki $S$, and Imai I (2018) Temporal variability of algicidal and growth-inhibiting bacteria at an eelgrass bed in the Ariake

Inaba N, Trainer V, Onishi Y, Ishii K-I, Wyllie-Echeverria S, and Imai I (2017) Algicidal and growth-inhibiting bacteria associated with seagrass and macroalga beds in Puget Sound, WA, USA. Harmful Algae, 62, 136-147.

Imai I, Inaba N, and Sakami T (2017) Environmentally friendly strategies for the prevention of harmful algal blooms using algicidal bacteria associated with seagrass Harmful Algae, 160-165.

Sakami T, Sakamoto S, Takagi S, Inaba N and Imai I (2017) Distribution of three algicidal Alteromonas sp. strains in seagrass beds and suriciding areas in the Seto inland Sea, Japan. Fish Sci, 83:113-121.

\section{Personal Response}

\section{Could this approach be used to suppress large algal} blooms, possibly by adding algal growth-limiting bacteria?

II I believe that introducing potentially invasive bacteria requires a very careful manner, assessing all the possible the resistance of coastal areas against harmful algal blooms by protection and restoration of seagrass beds and their microbial assemblages.

We hold the future in our hands, choosing to recover the
ecosystem services from seagrass beds we have lost.

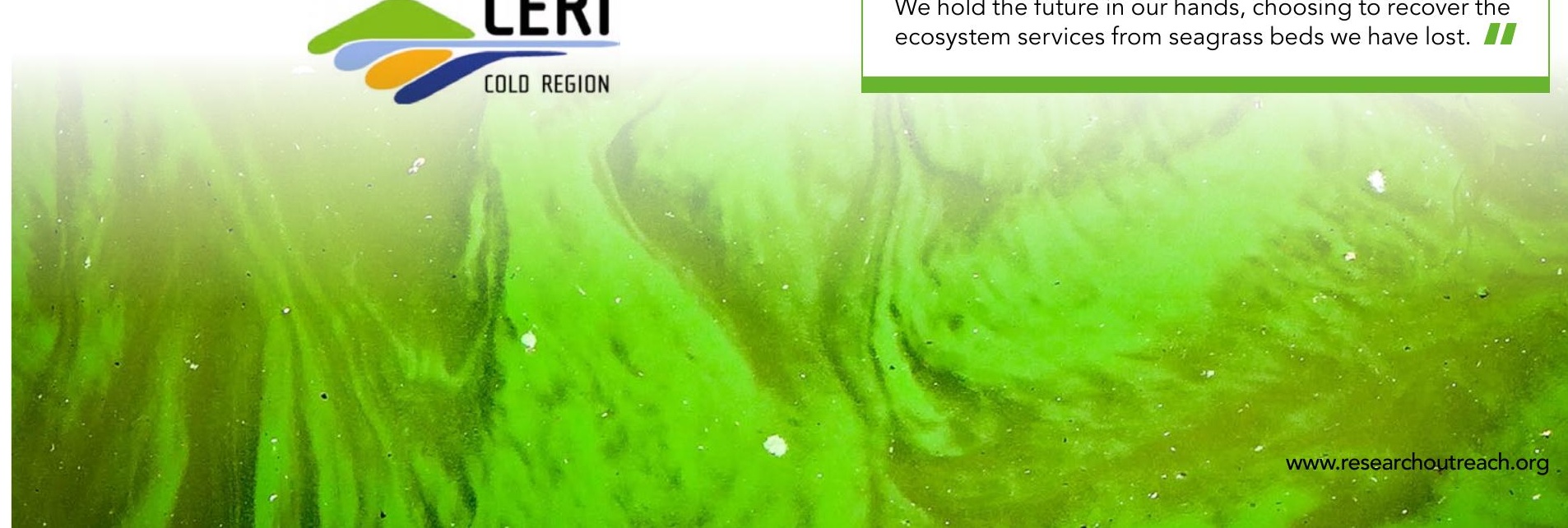

